\title{
A new species of the genus Alopecosa Simon, 1885 (Aranei: Lycosidae) from south-east Kazakhstan
}

\author{
Новый вид из рода Alopecosa Simon, 1885 (Aranei: Lycosidae) \\ из юго-восточного Казахстана
}

\author{
D.V. Logunov \\ A.B. Аогунов \\ The Manchester Museum, The University of Manchester, Oxford Road, Manchester M13 9PL, UK. E-mail: dpavuk@ngs.ru \\ Манчестерский Музей, Университет Манчестера, Оксфорд Роуд, Манчестер M13 9PL, Великобритания.
}

KEY WORDS: Central Asia, spiders, Aranei, Lycosidae, Alopecosa, new species.

КЛЮЧЕВЫЕ СЛОВА: Центральная Азия, пауки, Aranei, Alopecosa, новый вид.

ABSTRACT. The paper presents a description, diagnosis and brief notes on biology of a new burrowing wolf spider, Alopecosa marikovskyi sp.n. ( $\left.\sigma_{+}^{7}\right)$, from south-east Kazakhstan.

РЕЗЮМЕ. Статья содержит описание, диагноз и краткие заметки по биологии нового вида норных пауков-волков, Alopecosa marikovskyi sp.n. ( ( юго-восточного Казахстана.

\section{Introduction}

Alopecosa Simon, 1885 is a large genus of wolf spiders containing more than 160 named species [Platnick, 2013], of which the overwhelming majority has been recorded/described from the Palaearcrtic Region; only eight species are known from North America [Dondale, Redner, 1990]. A few species were described from the Oriental [e.g., A. balinensis (Giltay, 1935)] and Afrotropical [e.g., A. camerunensis Roewer, 1960] regions or even from the Neotropics [e.g., A. andesiana (Berland, 1913) or A. fulvastra Caporiacco, 1955], but these species are doubtfully congeneric with true Alopecosa and require revision. The revised European Alopecosa species were considered by Lugetti \& Tongiorgi [1969] in five species groups: fabrilis, pulverulenta, cursor, sulzeri and striatipes. However, this grouping hardly covers the entire diversity of the Palaearctic Alopecosa, which according to some authors [e.g., Marusik, Kovblyuk, 2011] needs to be further split up into a number of new genera.

The Asian fauna of Alopecosa (viz., Middle Asia, southern regions of Siberia, Mongolia and China) remains inadequately studied, with numerous poorly known or new species awaiting (re)description. The fauna of wolf spiders of Kazakhstan is no exception. It currently includes 104 species belonging to 17 genera, of which 32 species belong to Alopecosa [Logunov,
Gromov, 2012]. Five Alopecosa species were only recently described from western Kazakhstan [Ponomarev, 2007, 2008, 2009] while six others remains known from their original descriptions only (e.g, A. ermolaevi Saveljeva, 1972; A. kronebergi Andreeva, 1976).

The aim of the present work is to describe a new species of burrowing Alopecosa species from southeast part of Kazakhstan which has been reported as an unnamed species of burrowing wolf spiders in several popular books of Marikovsky [1978, 1983, 1990].

The specimens studied have been shared between the Zoological Museum of the Moscow University, Moscow, Russia (ZMUM; curator: K.G. Mikhailov) and the Manchester Museum, University of Manchester, Manchester, UK (MMUM; curator: D.V. Logunov). The terminology and format of description follow Logunov [2010]. Abbreviations used in the text and figures: AME - anterior median eye, ALE - anterior lateral eye, FC - functional conductor, Fm - femur, MA - median apophysis, Mt — metatarsus, Pl palea, PME - posterior median eye, PLE - posterior lateral eye, $\mathrm{Pt}$ - patella, $\mathrm{Tb}$ - tibia, $\mathrm{Tr}$ - tarsus. The sequence of leg segments in measurement data is as follows: $\mathrm{Fm}+\mathrm{Pt}+\mathrm{Tb}+\mathrm{Mt}+\mathrm{Tr}$ (total). All measurements are in $\mathrm{mm}$.

\section{Description}

Alopecosa marikovskyi sp.n. Figs 1-26.

Types. Male holotype (ZMUM) from Kazakhstan, Almaty [=Alma-Ata] Region, Kapchagai Territory, c. $4.9 \mathrm{~km} \mathrm{~W}$ of Arna $\left(43^{\circ} 46^{\prime} 39^{\prime \prime} \mathrm{N}, 77^{\circ} 01^{\prime} 58^{\prime \prime} \mathrm{E}\right)$, c. $520 \mathrm{~m}$ a.s.1., sandy hills, OctoberNovember 2012, A.A. Feodorov.

Paratypes: $1 \sigma^{7} 2$ 우 (ZMUM) and $1 \sigma^{7} 1 \%$ (MMUM, G7511.24), together with the holotype.

ETYMOLOGY. This new species is dedicated to the late Prof Pavel I. Marikovsky (1912-2008), the 

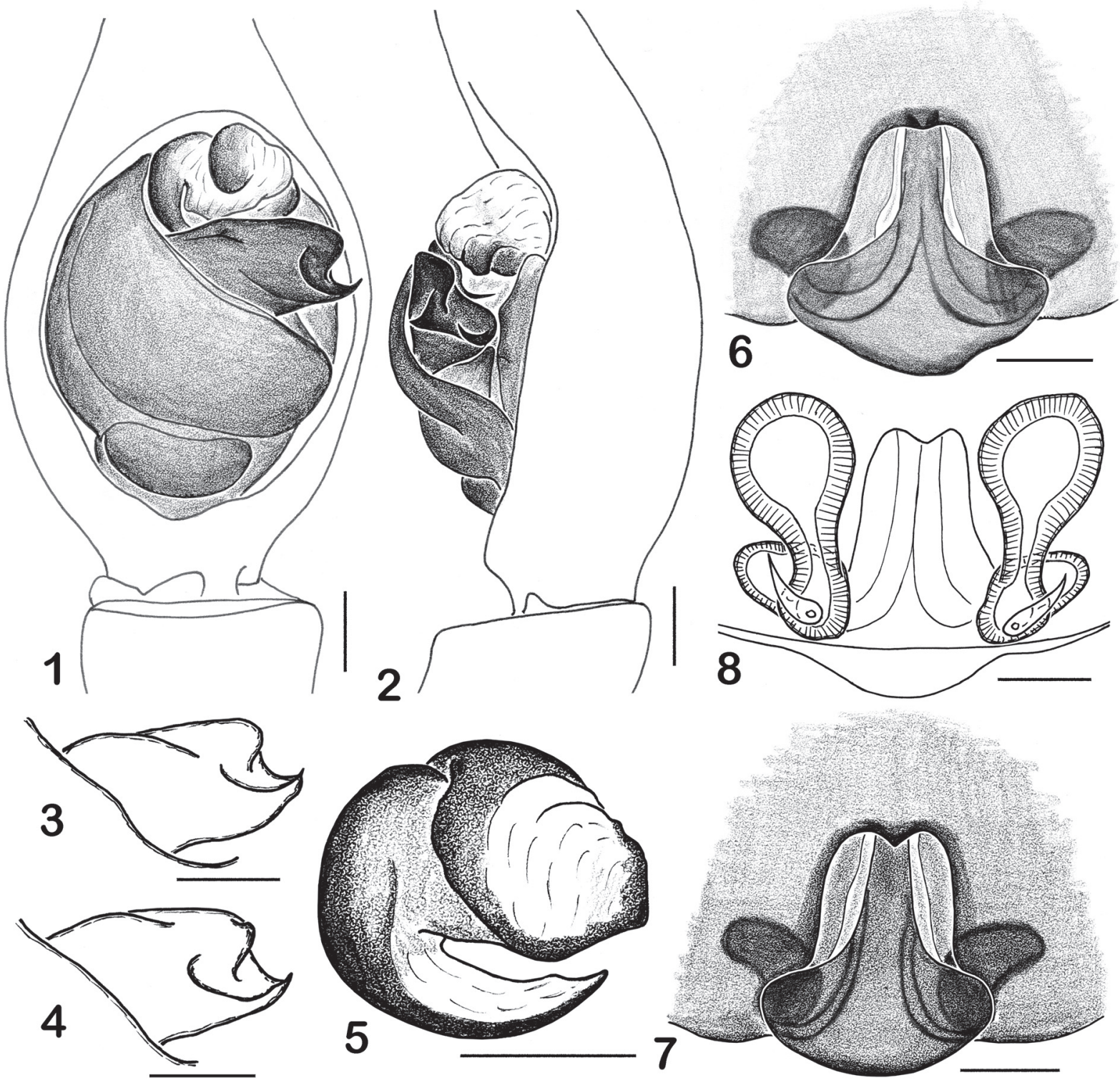

Figs 1-7. Copulatory organs of Alopecosa marikovskyi sp.n. (1-2, O' holotype): 1 - male palp, ventral view; 2 - ditto, retrolateral view; 3-4 - median apophysis, ventral view; 5 - palea and embolus, ventral view; 6-7 - epigyne, ventral view; 8 - spermathecae, dorsal view. Scale bar $0.25 \mathrm{~mm}$.

Рис. 1-7. Копулятивные органы видов Alopecosa marikovskyi sp.n. (1-2, о7 голотип): 1 — пальпа самца, вентрально; 2 - тоже, сбоку; 3-4 - медиальный апофиз, вентрально; 5 - палеа и эмболюс, вентрально; 6-7 - эпигина, вентрально; 8 - сперматека, дорзально. Масштаб 0,25 мм.

famous Russian naturalist and popularizer who wrote over 50 popular zoology, entomology and travel books, with which several generations of ecologists and entomologists of the former USSR have grown up. Furthermore, in some of his popular books [e.g., Marikovsky, 1978, 1983, 1990] he briefly mentioned (though not named) and illustrated with original photographs the new Alopecosa spider species described herein.

DIAGNOSIS. Alopecosa marikovskyi sp.n. does not fully fit the diagnosis of any of the species groups suggested by Lugetti \& Tongiorgi [1969]. The males are more similar to those of the fabrilis group while the females fit the pulverulenta group. The male of $A$. marikovskyi sp.n. differs from those of all the Alopecosa species known to me in having a strongly notched median apophysis (Figs 3-4, 9-11), a palea with a poorly marked pointed prominence (Fig. 5; cf. figs 5A-D in Kronestedt [1990]) and a very small and narrow functional conductor (arrowed in Fig. 9). The female can be distinguished by the shape of septal pedicel (Figs 6-7) and the ovoid receptacula with short insemination ducts (Fig. 8). Alopecosa marikovskyi sp.n. also differs from most other Alopecosa species in having no light median stripe on the carapace and the 

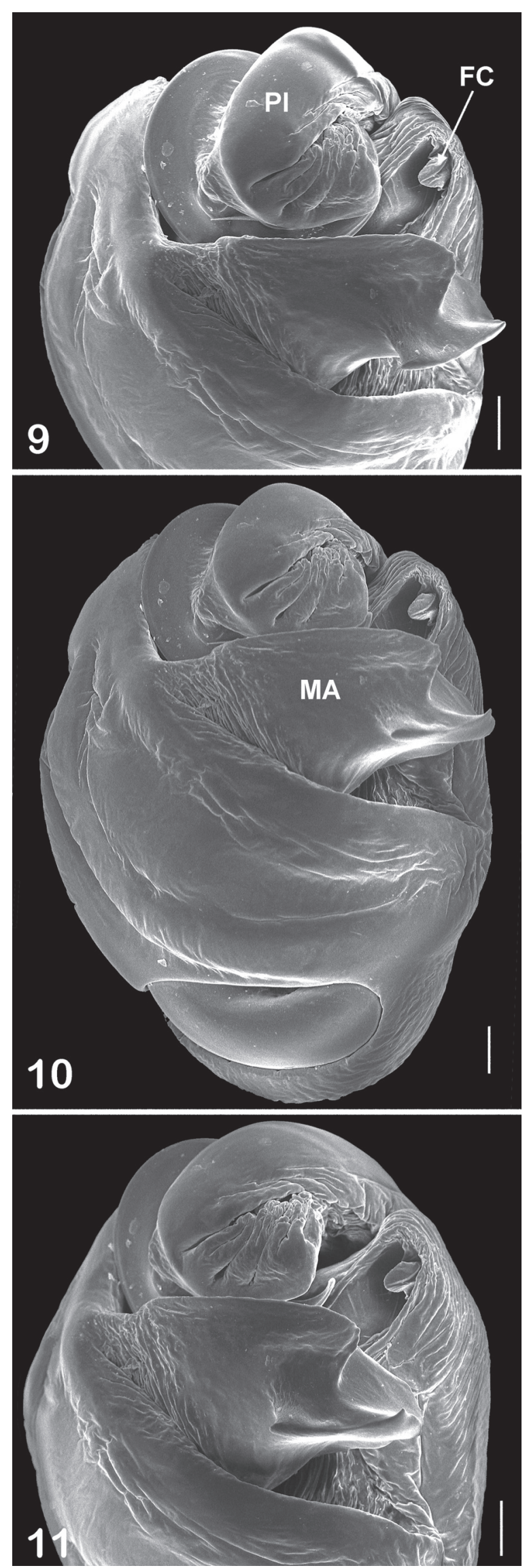

cardiac mark on abdomen (Figs 12, 14, 16-19) but instead being colored black ventrally as in many other large burrowing wolf spiders (Figs 13, 15).

DESCRIPTION. MALE (holotype). Carapace 7.60 long, 5.60 wide. Eye sizes and interdistances: AME 0.35, ALE 0.31, PME 0.73, PLE 0.65, AME-AME 0.20, AME-ALE 0.14, PME-PME 0.60, PLE-PLE 1.43. Width of anterior eye row 1.63, second row 1.88 , third row 2.38. Clypeus height 0.14, chelicera length 3.10. Abdomen 5.30 long, 3.95 wide. Length of leg segments: I $5.75+2.55+4.30+4.40+2.35(19.35)$; II $5.25+2.35+4.00+4.90+2.35(18.85)$; III $4.40+$ $2.40+3.50+5.25+2.50(18.05)$; IV $6.00+2.55+$ $5.20+6.70+2.55$ (23.00). Coloration (Figs 14-15). Carapace brown, densely covered with white hairs which are especially dense along carapace margins and on the eye field (Fig. 14). Sternum, maxillae and labium brown, densely covered with black hairs. Chelicerae dark brown, covered with back hairs. Abdomen: dorsum greyish brown, with a marked colour pattern of two longitudinal parallel lines of brown spots connected to each other by transverse brown lines; venter with a large black spot covering the area from epigastric furrow to spinnerets, but the book lungs and the surroundings of the spinnerets are covered with white hairs (Fig. 15). Legs: all coxae brown and densely covered with black hairs, remaining segments yellow and covered with white hairs; Mt and Tr structure as in the female (see below). Palps: Fm yellowish brown, Pt and Tb yellow, cymbium and bulbus brown; all palpal segments are covered with white hairs. Palpal structure as in Figs 1-5: the embolus is wide and visibly membraneous, the median apophysis is angular and elongated laterally, the palea with a poorly marked pointed prominence, the conductor is small and elongated.

Female (paratype from the MMUM). Measurements. Carapace 8.10 long, 5.30 wide. Eye sizes and interdistances: AME 0.38, ALE 0.30, PME 0.80, PLE 0.65, AME-AME 0.15, AME-ALE 0.18, PME-PME 0.63, PLE-PLE 1.53. Width of anterior eye row 1.73 , second row 2.03, third row 2.55. Clypeus height 0.20 , chelicera length 3.05. Abdomen 5.30 long, 3.95 wide. Length of leg segments: I $5.45+2.50+3.55+3.40+$ 2.10 (17.00); II $4.65+2.25+3.20+3.40+2.15$ $(15.65) ;$ III $4.10+2.20+2.70+3.50+2.15(14.65)$; IV $5.40+2.30+4.00+5.25+2.75(19.70)$. Coloration (Figs 12-13, 16-19). Carapace brown, with two wide marginal white stripes and a longitudinal median white line of hairs. Sternum, maxillae, labium and chelicerae as in the male. Abdomen as in the male, but with a better marked dorsal colour pattern (Figs 1619). Legs: all coxae brown and densely covered with black hairs, remaining segments yellow and covered

Figs 9-11. Bulbus of Alopecosa marikovskyi sp.n. (holotype): 9 - front view; 10 - ventral view; 11 - retrolateral view. Scale bar $100 \mu \mathrm{m}$.

Рис. 9-11. Бульбус Alopecosa marikovskyi sp.n. (голотип): 9 - вид спереди; 10 - вентрально; 11 - сбоку. Масштаб 100 $\mu \mathrm{m}$ 

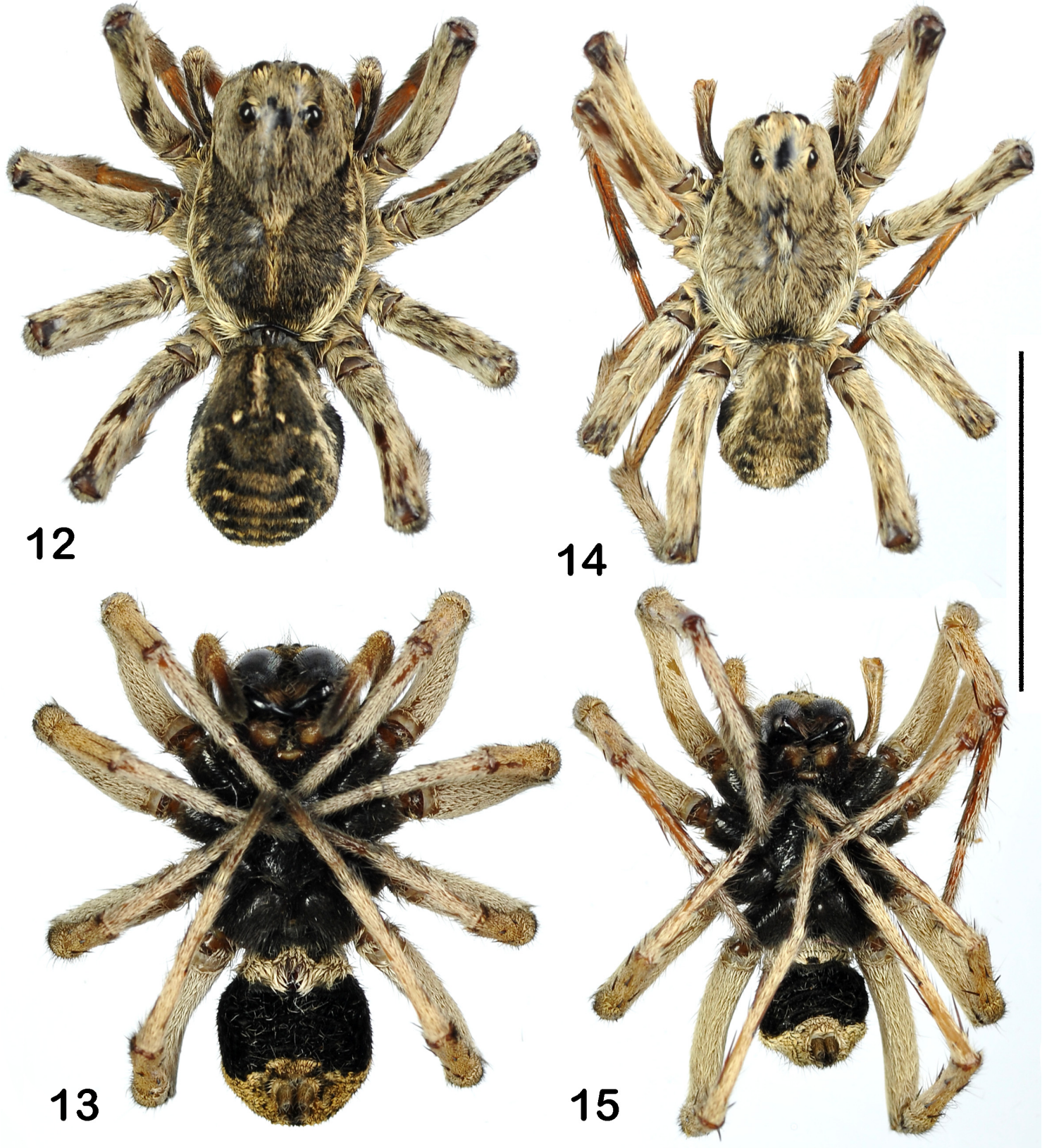

Figs 12-15. General appearance of Alopecosa marikovskyi sp.n. ( $\sigma^{7}$ holotype and $\odot$ paratype from the MMUM): 12 - female, dorsal view; 13 - ditto, ventral view; 14 - male, dorsal view; 15 - ditto, ventral view. Scale bar $10 \mathrm{~mm}$.

Рис. 12-15. Общий вид Alopecosa marikovskyi sp.n. (О голотип и † паратип из MMUM): 12 - самка, сверху; 13 - тоже, снизу; 14 - самец, сверху; 15 - тоже, снизу. Масштаб 10 мм.

with white hairs; Mt and Tr I-II ventrally with welldeveloped scopulae and longitudinal rows of poorly marked spinules (Fig. 20), Mt and Tr III-IV only with ventral longitudinal rows of hairs and spinules (Fig. 21). Palps: Fm and Tr yellowish brown, Pt and Tb yellow, all segments covered with white hairs. Epigyne and spermathecae as in Figs 6-8: the median septum vase-shaped, hood cavities are very small, closely set and poorly visible, the spermathecae with pear-shaped receptacles.
DISTRIBUTION. Kazakhstan: currently the type locality, but the species seems to be widely distributed across the entire Semirechie (Russian: Семиречье), the territory lying south-east of Lake Balkhash (A. Gromov, pers. comm.). Furthermore, there is at least one informal published record of this species from the land-locked basin of Sorbulak lying north-west of Almaty (about 15-20 km from the type locality) made by P.I. Marikovsky in one of his popular books [Marikovsky, 1978: 31] in his statement that "here, 


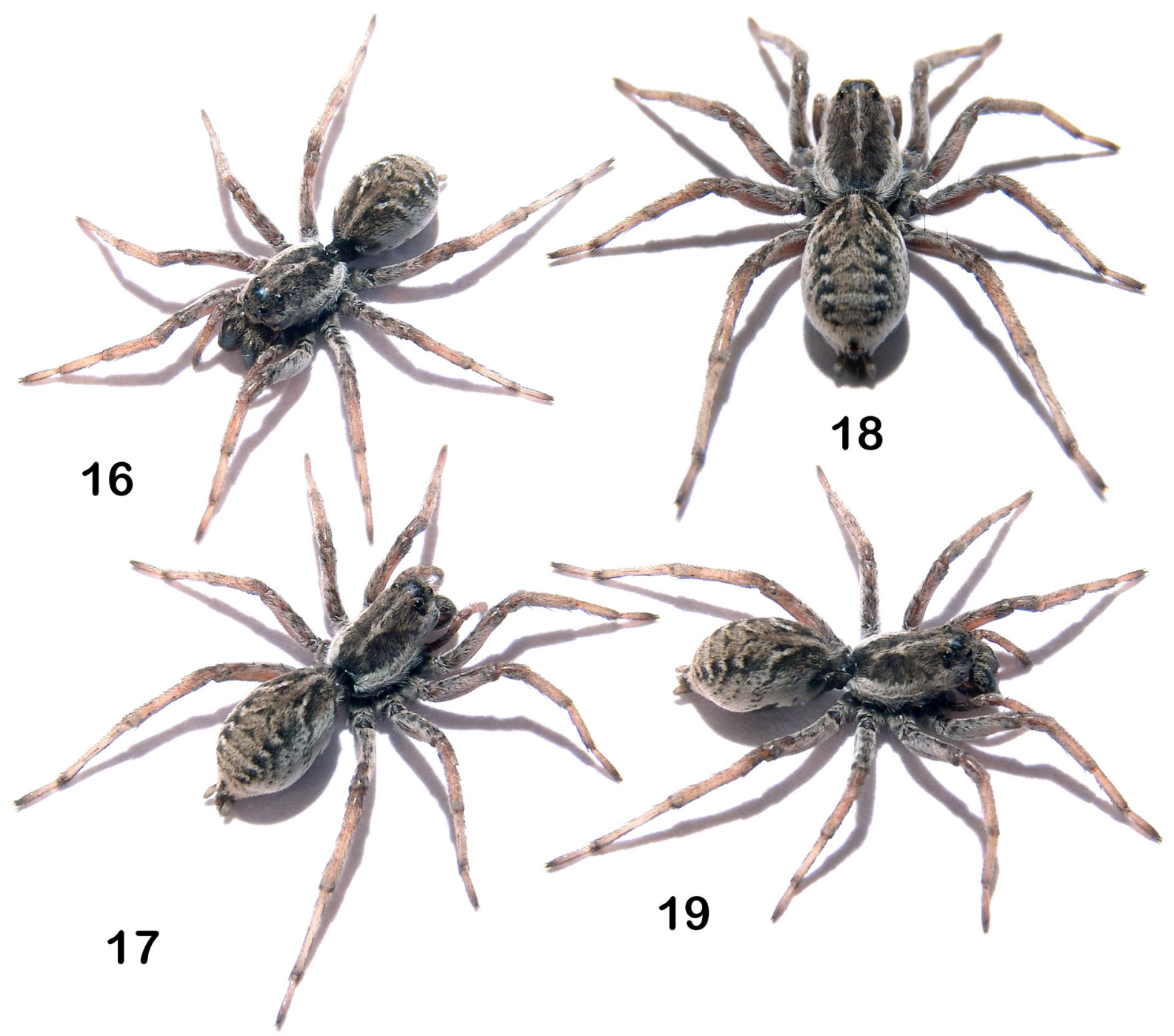

Figs 16-19. Female of Alopecosa marikovskyi sp.n. (paratype).

Рис. 16-19. Самка Alopecosa marikovskyi sp.n. (паратип).

everywhere there are burrows of desert tarantulas with carefully adjusted trapdoors" (translated from the Russian by DL). There is no doubt that the latter author dealt with A. marikovskyi sp.n., for in his other popular books [e.g., Marikovsky, 1983, 1990] he also published good original photos of the mature female of this species and its burrow with an opened trapdoor.

NATURAL HISTORY. Alopecosa marikovskyi sp.n. is a burrowing wolf spider occurring in saline deserts (fixed sands), with a density of 30-50 spiders per $1,000 \mathrm{~m}^{2}$ (A. Gromov, pers. comm.). Spiders are permanent burrowers making deep burrows (up to 50 $\mathrm{cm}$ ) with a trapdoor [Marikovsky, 1983]. The trapdoor is slightly protuberant, with concentric circles of silk seen on its inside, and is decorated with soil particles on its outer side. If disturbed, the spider immediately escapes into the burrow and closes the trapdoor with its hind legs. When closed, the trapdoor is well-camouflaged; trapdoors can be spotted only after rain because they dry out quicker than the neighbouring ground and look like whitish circles on the darker sandy background (V. Gromov, pers. comm.). Trapdoors are not self-closing and are often left open during daytime. Sometimes adult females do not care for their trapdoors which are kept open all the time or are even detached. In the latter case, despite the burrow appearing abandoned, the spider still remains inside.

\section{Discussion}

Although A. marikovskyi sp.n. (Figs 12-19) does not possess a light median stripe on carapace and a cardiac mark on the abdomen, which are the diagnostic colour characters of European Alopecosa species (see Nentwig et al. [2013]), it is indeed a member of this genus possessing its main diagnostic characters [sensu Dondale \& Redner, 1990]: medium body size; cheliceral retromargin with two teeth; femur I with a prolat- 

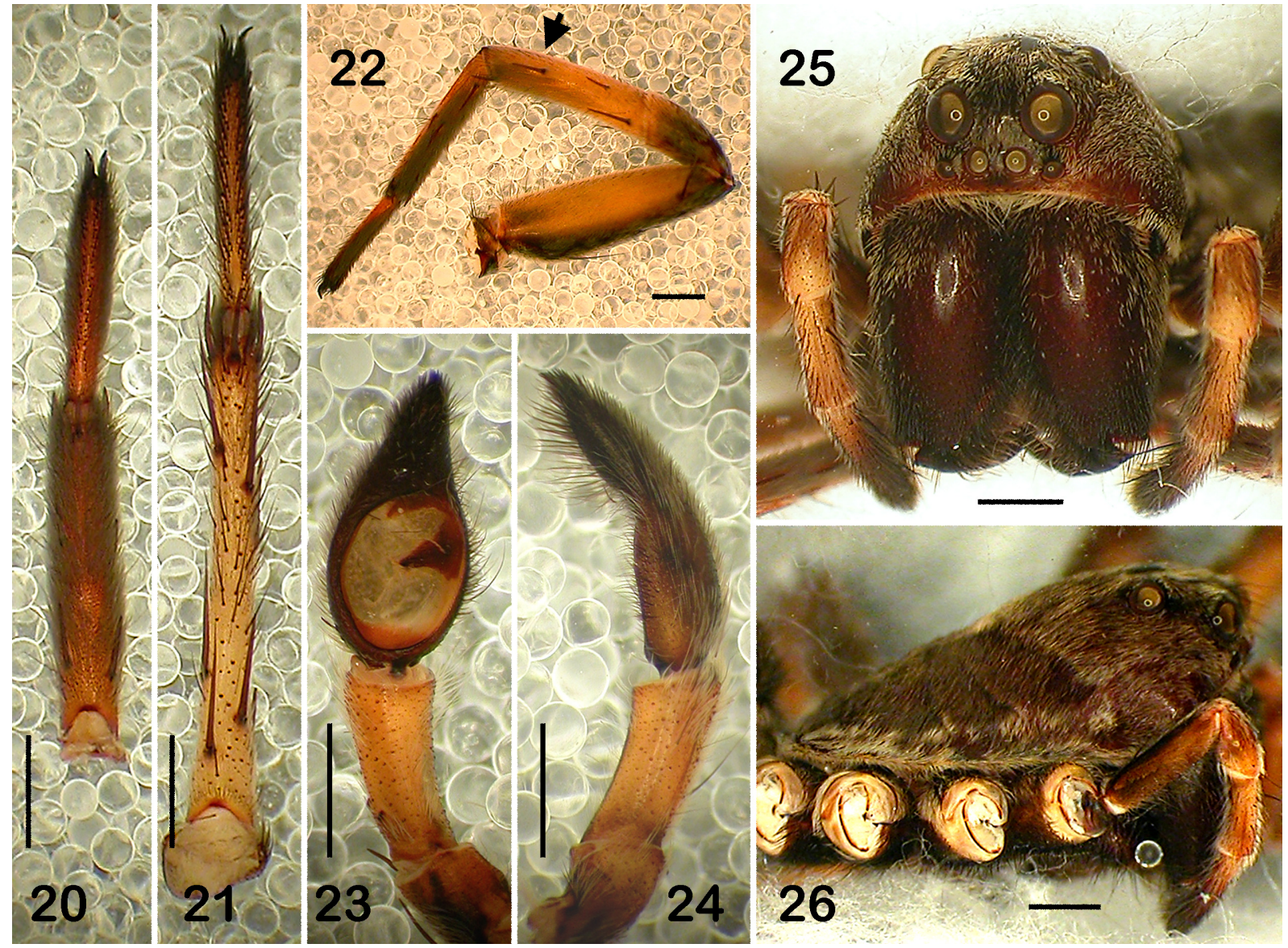

Figs 20-26. Somatic characters of Alopecosa marikovskyi sp.n. ( $\sigma^{7}$ holotype and 9 paratype from the MMUM): 20 - female Mt and Tr IV, ventral view; 21 - female Mt and Tr IV, ventral view; 22 - leg I, female, prolateral view; 23-24 - male palp, ventral and retrolateral views; 25 - female face, front view; 26 - female carapace, lateral view. Scale bar $1 \mathrm{~mm}$.

Рис. 20-26. Соматические признаки Alopecosa marikovskyi sp.n. (О голотип и ㅇ паратип из MMUM): 20 — Mt and Tr IV самки, вентрально; 21 - Mt and Tr IV самки, вентрально; 22 - нога I, самка, спереди; 23-24 - пальпа самца, вентрально и сбоку; 25 фейс самки, спереди; 26 - карапкс самки, сбоку. Масштаб 1 мм.

eral spine (arrowed in Fig. 22); the angular median apophysis (Figs 3-4, 9-11); the palea with a poorly marked pointed prominence (Fig. 5); the median septum of the epigyne vase-shaped (Figs 6-7); and the hood cavities are very small and closely set (Fig. 6). At the same time, this species possesses all the main morphological characteristics reflecting its burrowing lifestyle [sensu Zyuzin, 1990, 1993]: the prominent slope of the carapace (Fig. 26), being similar to those of true borrowers from such genera as Allohogna Roewer, 1955 or Oculicosa Zyuzin, 1993 (see Logunov [2010: figs 3,5$]$ ); the black ventral colour pattern on the sternum, coxae and abdomen (Figs 13, 15); the fur-like pubescence on the carapace (Figs 12, 14); and a cluster of rigid and straight bristles on the cymbial tips in male palps (Figs 23-24).

Burrowing behaviour in the Lycosidae is not restricted to a single tribe or subfamily and is likely to have evolved several times. Although the majority of burrowing wolf spiders belong to the traditional Lycosinae, which includes Alopecosa [Zyuzin, 1990; Murphy et al., 2006], examples also include such genera as
Tetralycosa Roewer, 1960 of uncertain placement from Australia or Xerolycosa Dahl, 1908 (Evippinae) from the Palaearctic Region (see Logunov [2011], for full discussion). It is interesting to note that although to date burrowing behaviour has been described for only a few Alopecosa species, the type species of the genus (A. fabrilis (Clerck, 1758)) also makes rather deep silk-lined burrows in sandy soil [Nielsen, 1932: fig. 199; sub. Tarentula f.]. However, burrows with trapdoors, similar to that described for A. marikovskyi sp.n. [Marikovski, 1983: 130], have never been reported for Alopecosa species to date.

ACKNOWLEDGEMENTS. I am most grateful to the following colleagues who helped me during preparation of the present work: Alexander and Vitaly Gromov (Almaty, Kazakhstan) for sharing with me their personal field observations on A. marikovskyi sp.n., Phillip Rispin (Manchester, UK) for making the digital images of the general appearance of the studied specimens, Andrei A. Feodorov (Almaty, Kazakhstan) for the photos of female (Figs 16-19), Yuri Marusik (Ma- 
gadan, Russia) for making SEM photos of the male bulb and commenting on the early draft, and Anthony Russell-Smith (Kent, UK) for kind linguistic help.

\section{References}

Dondale C.D., Redner J.H. 1990. The wolf spiders, nurseryweb spiders, and lynx spiders of Canada and Alaska. The Insects and arachnids of Canada, part 17. Ottawa, Canada. 383 pp.

Kronestedt T. 1990. Separation of two species standing as Alopecosa aculeata (Clerck) by morphological, behavioural and ecological characters, with remarks on related species in the pulverulenta group (Araneae, Lycosidae) // Zoologica Scripta. Vol.19. P.203-225.

Logunov D.V. 2010. On new central Asian genus and species of wolf spiders (Araneae: Lycosidae) exhibiting a pronounced sexual size dimorphism // Proc. Zool. Inst. RAS. Vol.314 No.3. P.233-263.

Logunov D.V. 2011. Sexual size dimorphism in burrowing wolf spiders (Araneae: Lycosidae)// Proc. Zool. Inst. RAS. Vol.315. No.3. P.274-288.

Logunov D.V., Gromov A.V. 2012. Spiders of Kazakhstan. Manchester: Siri Sci. Press. 232 pp.

Lugetti G., Tongiorgi P. 1969. Ricerche sul genere Alopecosa Simon (Araneae-Lycosidae) // Atti della Societa Toscana di Scienze Naturali, Memorie. Serie B. Vol.76. P.1-100.

Marikovsky P.I. 1978. [In the deserts of Kazakhstan]. Moscow: Mysl. 127 pp. [in Russian]

Marikovsky P.I. 1983. [In the insect world with a camera]. AlmaAta: Kainar. 136 pp. [in Russian]

Marikovsky P.I. 1990. [Black widow: a story of the poisonous spider Karakurt and other arachnids]. Alma-Ata: Kazakhstan. 192 pp. [in Russian]

Marusik Yu.M., Kovblyuk M.M. 2011. [Spiders (Arachnida, Aranei) of Siberia and the Russian Far East]. Moscow: KMK Scientific Press Ltd. 344 pp. [in Russian]
Murphy N.P., Framenau V.W., Donnellan S.C., Harvey M.S., Park Y.C., Austin A.D. 2006. Phylogenetic reconstruction of the wolf spiders (Araneae: Lycosidae) using sequences from the 12S rRNA, 28S rRNA, and NADH1 genes: implications for classification, biogeogreaphy, and the evolution of web building behaviour // Mol. Phyl. Evol. Vol.28. P.583-602.

Nentwig W., Blick T., Gloor D., Hänggi A., Kropf C. 2013. Spiders of Europe (version 3.2013), online at: www.araneae.unibe.ch (accessed on March, 3, 2013).

Nielsen E. 1932. The biology of spiders, with special reference to the Danish fauna. Vols I-II. Copenhagen: Levin and Munksgaard. 248; 723 pp.

Platnick N.I. 2013. The world spider catalog, version 13.5. American Museum of Natural History, online at: http://research.amnh. org/entomology/spiders/catalog/index.html (accessed 3 March 2013).

Ponomarev A.V. 2007. [New taxa of spiders (Aranei) from the southern part of Russia and western Kazakhstan] // Caucasian Entomol. Bull. Vol.3. P.87-95 [in Russian].

Ponomarev A.V. 2008. [Additions to the spider fauna (Aranei) of the southern part of Russia and western Kazakhstan: new taxa and records] // Caucasian Entomol. Bull. Vol.4. P.49-61 [in Russian]

Ponomarev A.V. 2009. [New species and records of spiders (Aranei) from the southern part of Russia and western Kazakhstan] // Caucasian Entomol. Bull. Vol.5. P.143-146 [in Russian].

Zyuzin A.A. 1990. Studies on burrowing spiders of the family Lycosidae (Araneae). I. Preliminary data on structural and functional features // Acta Zool. Fennica. Vol.190. P.419-422.

Zyuzin A.A. 1993. Studies on the wolf spiders (Araneae: Lycosidae). I. A new genus and new species from Kazakhstan, with comments on the Lycosinae // Mem. Queensland Mus. Vol.33. No.2. P.693-700.

Responsible editor K.G. Mikhailov 